\title{
Institutional Capacity in Clean Water Management in Jeneponto Regency
}

\author{
Herlina Sakawati ${ }^{1}$, Sulmiah ${ }^{2}$, Novayanti Sopia Rukmana ${ }^{3}$, Widyawati ${ }^{4}$, Andi Tenri \\ Citra Sari ${ }^{5}$ \\ ${ }^{1} 2^{\prime} 3^{\prime} 4$ Public Administration Science, Fakultas Ilmu Sosial, Universitas Negeri Makassar \\ ${ }^{5}$ STAI YAPIS Takalar \\ Email: herlinamappakanro@gmail.com
}

(Received: September 6-2019; revised: November 15-2019; published: December 31-2019)

\begin{abstract}
This study aims to analyze the institutional capacity in Jeneponto Regency in the management of clean water. The study was conducted using descriptive qualitative methods. Data collection is done through observation and interview techniques, which are strengthened from data from related institutions. The results showed that five dimensions were used to look at institutional capacity, only one dimension contributed to increasing the existing institutional capacity, namely the Social Norms, Values and Practice dimensions. And for the other four dimensions namely, individual dimensions, organizational dimensions, organizational network dimensions, and public governance dimensions still need to be improved. Institutional capacity in the management of clean water in Jeneponto Regency requires rules that govern cooperation between all agencies that have a connection in the management of clean water. The government needs to give training and education to employees.
\end{abstract}

Keywords: Capacity; Institution; management; and clean water

\section{INTRODUCTION}

Climate change that occurred in recent years has attracted the attention of many groups, including researchers in various countries. Many studies have shown that climate change has a negative effect on the availability of clean water, (Mizyed, 2009; Iglesias, Garrote, Flores, \& Moneo, 2006). This is caused by rising sea levels, flood disasters, changing intensity of rainfall and drought.

The availability of clean water is the thing most needed by the community in carrying out activities. Therefore, the role of the government in the management of clean water is needed. This is certainly inseparable from the institutional capacity. Because one of the success factors in clean water management lies in the participation of stakeholders and policies, (McNeill, 2016). In addition, institutional capacity is also one of the keys to success in regional development (Willems \& Baumert, 2003; Widyawati, Widianingsih, \& Pancasilawan, 2018) including the development of water resources.

In Indonesia, clean water management is guided by Law No. 11 of 1974. Based on these regulations clean water management is the responsibility of the central government. If it is related to regional autonomy policy, this is certainly contrary to the principle of decentralization. Since the enactment of regional autonomy, local governments have the authority to explore their own regional potential, including the management of water resources. So that Law No. 11 of 1974 is considered to be incompatible with current conditions. Where 
296 Jurnal Ilmiah Ilmu Administrasi Publik: Jurnal Pemikiran dan Penelitian Administrasi Publik

Volume 9 Number 2, July- December 2019. Page 295-304

local governments do not have the authority in formulating water management policies in their own regions.

Inequality in clean water management policies has an impact on water management patterns in several regions in Indonesia. One of the efforts made by the government to improve clean water management is by optimizing the role of PDAMs in each region. However, the performance of PDAMs is still less than optimal. Various problems with the availability of clean water felt by the community are caused by the ineffectiveness of the services provided by the PDAM.

One area that has problems in managing clean water to meet the availability of water for the community is the Jeneponto Regency in South Sulawesi Province. From the data obtained, the availability of clean water in Jeneponto Regency is still lacking. This is due to the Jeneponto Regency which is a coastal area. In addition, Jeneponto regency's raw water source which originates from the Kelara River every dry season experiences drought, and when the rainy season arrives the source of raw water is polluted.

From the results of a feasibility study conducted by the United States Agency for International Development (USAID), through the Indonesia Urban Water, Sanitation, and Hygiene (IUWASH) program, to improve the performance of PDAMs in water management, PDAMs are required to carry out all activities related to clean water management in order to meet the needs of the community, such as monitoring the quantity, quality, continuity and affordability of raw water. However, so far the results of the feasibility study have not shown any changes to the PDAM's performance.

In addition, the role of the Jeneponto district government in supporting PDAM performance is less than optimal. Local governments do not provide various facilities and infrastructure for the sake of improving PDAM performance. In the management of clean water in Jeneponto Regency there is also no coordination relationship between the government and the Jeneponto PDAM. Coordination between all government officials and other parties basically aims to develop clean water management patterns, so that clean water management can run as expected.

New Zealand and Japan are examples of countries that have successfully implemented clean water management. This success was driven by good coordination between the national government, the provincial government and the government and the involvement of the private sector. Based on this, a study entitled Institutional Capacity in Clean Water Management in Jeneponto Regency, which aims to know the institutional capacity that exists in Jeneponto Regency in water management.

\section{METHOD}

Government involvement and the ability of PDAMs in managing clean water in Jenponto Regency is still low. This then encourages researchers to use a descriptive qualitative approach in analyzing institutional capacity in water management in Jeneponto. The data from this study consisted of primary and secondary data, which researchers obtained from observations, interviews, and documentation studies. The informants in this study were determined using the snowball technique, which according to (Nemuan, 2013)the informants were determined based on the information that had been obtained, which then became a reference for determining the 
next informant. Informants in this study consisted of, the Director of the Jeneponto Regency PDAM, the Head of the Jeneponto Regency PDAM Finance, the Jeneponto Regency Deputy Regent, the Jeneponto Regency PDAM employee, and the Jeneponto Regency community. For data analysis, use data analysis techniques proposed by (Miles, Huberman, \& Saldana, 2014) called interactive models, which consist of data reduction, data display, and conclusion, drawing / verification.

\section{RESULT AND DISCUSSION}

This study discusses institutional capacity in clean water management in Jeneponto Regency. Institutional analysis is used by using theoretical tools from Willems \& Baumert, 2003, which consists of dimensions of individual capacity, organizational capacity, Network of Organization, Public Governance, and Social Norms, Values and Practice. The results and discussion of further research will be explained as follows:

\section{The Individual}

The individual dimension in the management of clean water is related to the performance of employees in carrying out their duties. The function of employee performance is the basis of success in achieving a goal. Relating to institutional capacity, the effectiveness of individual performance is influenced by the compatibility between educational background and skills with work, providing training, and the availability of the number of employees.

As an organization that plays an important role in the management of clean water, PDAM Kabupaten Jeneponto must have an adequate number of human resources. To calculate HR needs or the number of employees needed, it is important to pay attention to the ratio of the number of employees to the number of customers. In accordance with the standard Operational Aspects of the PDAM Performance Audit, it is known that the ratio of 8 employees per 1,000 customers, or in other words one (1) employee serves 125 house / customer connections.

The number of PDAM customers in the Jeneponto Regency as of July 2019 was 9,800 house connections. Ideally, employees need around 79 people to serve these customers. From the data obtained, it is known that the Jeneponto Regency PDAM has 93 employees, consisting of 84 permanent employees, and 9 contract / voluntary employees. So that in terms of the need for human resources (HR) in PDAM Jeneponto Regency is classified as sufficient.

In relation to the level of education, the education of Jeneponto District PDAM employees is relatively low. There are still Jeneponto Regency PDAM employees who have educational levels only up to elementary school (SD) graduates, and still relatively few who have education levels up to the undergraduate level (S1). The educational background of PDAM Jeneponto Regency employees is dominated by high school graduates. For more details can be seen in the following table: 
298 Jurnal Ilmiah Ilmu Administrasi Publik: Jurnal Pemikiran dan Penelitian Administrasi Publik Volume 9 Number 2, July- December 2019. Page 295-304

Table 1

Educational Background of Employees

\begin{tabular}{cccc}
\hline No & Educational & Permanent employee & Contract / Voluntary Employees \\
\hline 1 & SD & 2 & 3 \\
2 & SMP & 4 & - \\
3 & SMA/SMK/MAN & 58 & 6 \\
4 & S1 & 20 & - \\
\hline & Amount & 84 & 9
\end{tabular}

Source: Author's Process, 2019

In the table above, it can be seen that 58 employees have backgrounds up to the middle level, which consists of graduates, high schools, vocational schools, and MAN. Of the 58 employees, 46 of them are high school graduates (dominantly majoring in social studies), 7 graduates of SMK, and 5 graduates of MAN. Whereas at the graduate level, there are only 6 employees who have educational backgrounds that are not suitable for the job. The six (6) employees, 2 of whom were graduates of the Agricultural Social Sciences S1, 1 graduate of Religious Education S1, and 3 graduates of S1 Education. The other fourteen (14) employee are S1 Economics graduates.

The low educational background and non-conformance with work are influenced by the employee recruitment system. Recruitment of employees at the Jeneponto Regency PDAM Office has similarities with various government agencies and other BUMNs. The recruitment process has several requirements and stages. However, in education qualifications, the PDAM Office does not emphasize the educational background with the required job vacancies. PDAM Jeneponto Regency, for the requirements only determine the minimum educational qualifications of high school graduates, so that many applicants who have educational backgrounds that are not in accordance with the work required take part in applying for a job.

Furthermore, with regard to employee skills, Jeneponto Regency PDAM employees have relatively low skills. Employees do not have sufficient skills to innovate in terms of improving services and improving clean water management. This is caused by the absence of efforts made by the leadership to develop employee capacity.

Based on the results of the study, employees in other institu- tions who have a relationship with PDAM Jeneponto Regency in the management of clean water, such as the Regional Government, Health Office, BPKP Representative Prov. South Sulawesi, Office of Public Works, Office of Environment, Center for Water Resources, in general have education that is not suitable for work, and have low ability to innovate in carrying out work. In addition, employees are classified as lacking discipline. Many employees often arrive late.

Basically, one of the most important aspects of clean water management in Jeneponto Regency is the skills possessed by employees. Although employees do not have a high education but have good skills, it will certainly make water management better. This is as stated by (Gibson \& Donnelly, 2000)that "employee skills have a considerable influence on 
performance, if employees are able to apply the skills they have in carrying out work". Furthermore (Dunnete, 1976)emphasized that employee skills can be developed through the provision of training. Therefore, in the management of clean water in the Jeneponto Regency, the local government needs to pay attention and carry out training and education provision, especially for the Jeneponto Regency PDAM, and all agencies that have a relationship in managing clean water in general.

\section{The Organization}

In addition to the individual dimension, the organizational dimension is also the key to success in the management of clean water in Jeneponto Regency. This relates to the mechanism of work and the capacity of organizational resources involved in the management of clean water in Jeneponto Regency.

One of the things that can be done to maintain the availability of water in Jeneponto Regency is to carry out regular monitoring of natural assets and the built assets of PDAM Jeneponto Regency. Natural assets need to be considered because to know the condition of raw water sources and various hydrological characteristics of the catchment area and its surroundings. And the assets built are useful for knowing the condition and status of the asset, both the remaining technical life, maintenance and repair schedules and estimated repair costs.

Monitoring of natural assets include, spring discharge, river discharge, river water level, spring quality, borehole quality and river water quality. This relates to the role of the Jeneponto Regency Health Office, the Jeneponto Regency Water Resources Center, and the Jeneponto Regency Environmental Agency. But so far the cooperation relationship with these agencies is not going well. In accordance with the 2015 IUWASH (Indonesia Urban Water, Sanitation, and Hygiene) report, it was explained that regular monitoring of PDAM's natural assets was needed, because the data affected the institutional capacity in managing clean water, especially the PDAM of Kabupaten Jeneponto.

In reality on the ground, only the Jeneponto District Health Office has helped a lot in managing clean water. Every six (6) months the Health Office will provide a monitoring report on the quality of raw water sources, but its nature is only on invisible monitoring. For visible monitoring, such as the quality of odor, taste and color of raw water sources, it is still carried out by the PDAM of Jeneponto Regency.

Seeing that the condition of the Jeneponto Regency PDAM is very alarming, the Regional Government of the Jeneponto Regency should provide assistance, as well as the Public Works Agency (PU), because the Jeneponto Regional Government is the owner of the PDAM itself, and the Public Works Agency has the responsibility to assist the PDAM in matters infrastructure physical operations. But in reality both parties seemed to close their eyes to see the condition of the Jeneponto Regency PDAM.

The lack of attention from agencies involved in the management of clean water, causes obstacles for PDAMs to carry out monitoring of built assets. There are a number of PDAM assets that must be replaced and repaired, such as water tank trucks that are 20 years old and facilities and infrastructure damaged by floods. And according to PDAM employees, a proposal for funding assistance to improve the infrastructure has been submitted to the Regional Government of Jeneponto Regency, but until now the budget has not been disbursed. 
300|Jurnal Ilmiah Ilmu Administrasi Publik: Jurnal Pemikiran dan Penelitian Administrasi Publik

Volume 9 Number 2, July- December 2019. Page 295-304

Furthermore, as an organization that plays an important role in the management of clean water in the Jeneponto Regency, the PDAM of the Jeneponto Regency also has limitations in terms of organizational resources. District PDAMs have low human resources. In addition, since 2017, the PDAM of Jeneponto Regency has a financial problem, which is caused by corruption committed by the Director of the PDAM in the 2014-2017 period. And the most alarming situation is that at the beginning of 2019, the PDAM of Jeneponto Regency was again faced with a new problem, where the flood disaster that struck Jeneponto, made most of the facilities and infrastructure of the PDAM badly damaged.

Based on the discussion above, it can be concluded that the institutional capacity in the management of clean water in Jeneponto Regency still has poor organizational capacity. Every organization involved in clean water management does not carry out its role. This is due to the absence of rules regarding the work system of the relevant agencies in the management of clean water. In addition, the Jeneponto Regency PDAM is still trying to rise from adversity, so that it has not been optimal in clean water management.

\section{Network of Organization}

Network of organizations or network of organizations in the management of clean water in Jeneponto Regency, will discuss the relationship of cooperation, coordination and communication, which is carried out by all parties involved in the management of clean water. The complexity of clean water management requires the support of cooperation and high commitment from various parties. According to the General Assembly of the United Nations (UN) the cooperation of all parties in the management of clean water is to maintain a balance between the various needs and different priorities for water. The parties referred to in this matter are, the Central Government, Provincial Governments, Regional Governments and PDAM of Jeneponto Regency, as the organization responsible for water management in Jeneponto Regency.

After the United Nations established, 2013 as the International Year of Water Cooperation, the central government in this case the Ministry of Finance made a policy related to water management. The policy is expected to help local governments and PDAMs to improve clean water management in their respective regions.

However, in its implementation, various facilities and incentives that have been provided by the Ministry of Finance cannot be implemented by the Jeneponto Regency PDAM, because one of the requirements for carrying out the program / policy issued by the Ministry of Finance, only PDAMs are in good health status (Directorate General of Human Settlements, 2013 ). While the PDAM of Jeneponto Regency is still classified as one of the PDAMs that is sick (Ministry of Public Works and Public Housing, 2017). In addition, the commitment of the Jeneponto Regency Government to the acceleration of clean water services is relatively low.

esides that, DPRD, BPKP Representative Prov. South Sulawesi and the Regional Government of Jeneponto Regency, so far, has never discussed investment credit for the Jeneponto Regency PDAM. Even though when this is done it is not impossible, for PDAM Jeneponto Regency can overcome the financial crisis that is being faced. Furthermore, the Regional Government of Jeneponto Regency also never tried to think of a strategic step in 
revitalizing the Jeneponto Regency PDAM. Whereas in Jeneponto Regency, clean water is increasingly difficult, while the population is growing exponentially.

Furthermore, with regard to the coordination relationship, the Supervisory Board plays a more important role as a bridge between the Government of the Jeneponto Regency and the Jeneponto Regency PDAM. This is caused by the absence of cooperative relations. When there is a problem in the management of clean water, the Jeneponto PDAM often coordinates with the Board of Trustees. With the reason, the supervisory board has the function to oversee all employee performance, and has the role of providing input to improve PDAM performance. When there are problems that are difficult to solve, the Supervisory Board will coordinate directly with the Regional Government.

Furthermore, for communication in the management of clean water in the Jeneponto Regency, the PDAM of the Jeneponto Regency has not been able to create an effective communication relationship related to the management of clean water. Whereas in this industrial era, the use of technology can facilitate the establishment of communication between all parties. The PDAM of Jeneponto Regency so far does not have its own website. In fact, almost all organizations both public and private organizations have used the website to facilitate customers to obtain information.

\section{Public Governance}

This indicator discusses the broader institutional context, which includes public sector regulation, and legal regulations in water management in Jeneponto district. The overall effectiveness of the public sector in the management of clean water is also influenced by several dimensions including political economy, and other legal rules.

After the cancellation of Law No.7 of 2004 concerning Water Resources, and the reenactment of Law No. 11 of 1974 concerning Irrigation, the government does not have a legal umbrella in the management of drinking water, because all derivatives of Law No. 7 of 2014 was also canceled. So that it causes overlapping policies in the management of clean water, because the existing laws are not in accordance with the current conditions.

In Jeneponto District, the PDAM has implemented a strategy to improve drinking water services to the community, by developing a Water Supply System (RI-SPAM) Master Plan. In the draft, there is something quite interesting that there are several points that discuss the involvement of the private sector, for example when BUMD in this case the PDAM of Jeneponto Regency is considered unable to improve the quantity and quality of SPAM services, then with the approval of the supervisory board / commissioner can include cooperatives, private business entity, and / or community.

Furthermore, in terms of SPAM development financing includes financing to build, expand and improve physical systems (technical) and non-physical systems can come from the Government and / or Regional Governments, BUMN / BUMD, cooperatives, private business entities, community funds and / or other sources of funds. The source and pattern of funding do not rule out the possibility of involving the private sector.

Some points in the Republic of Indonesia-SPAM Jeneponto, when we associate with regulations relating to the management of clean water, of course this is contrary to the applicable law, because in the law, clean water management is the responsibility of the government and is not allowed to intervene the hands of private parties. 
302 Jurnal Ilmiah Ilmu Administrasi Publik: Jurnal Pemikiran dan Penelitian Administrasi Publik

Volume 9 Number 2, July- December 2019. Page 295-304

However, when looking at the condition of the PDAM of Jeneponto Regency, the PDAM cannot conduct effective and efficient water management. In addition to the problem of low staff capacity, budget problems also make PDAM performance worse. And what needs to be understood is that in the management of clean water, it certainly requires a significant amount of costs, starting from the provision of water to distribution to the community, all of which require costs, with the condition of the PDAM that is certainly needed by other parties to help the PDAM in the Regency of Jeneponto in clean water management.

Basically, the involvement of the private sector in the management of clean water consists of several forms of cooperation, depending on the carefulness of the government to choose the form of cooperation that can benefit the community and the government itself in the management of clean water. According to the Deputy Regent of Jeneponto Regency, it is possible that someday there will be a cooperative relationship between the Regional Government and the private sector in the management of clean water.

In addition, in the management of clean water in the Jeneponto Regency, the Regional Government does not have rules governing water management carried out by the PDAM of the Jeneponto Regency. And to carry out clean water management PDAM Jeneponto Regency only refers to the rules of the Association of Indonesian Drinking Water Companies (PERPAMSI).

\section{Social Norms, Values and Practice}

On this indicator, norms, values and practices indicate the cultural, economic and social environment of an area. The implementation of clean water management is also significantly influenced by the community (socio-cultural) environment. The suitability of policies in the management of clean water to the community environment is able to create a good cooperative relationship between the government and the community, increase community participation and increase the sense of community responsibility for water management.

The PDAM of Jeneponto Regency to provide water services to the community has built several Water Treatment Plants (IPA) located in Binamu District, Turatea District and Bangkala District. The construction of the Natural Sciences is in residential areas.

The construction of natural sciences in the three districts was welcomed by the local community. Even though they have to pay tariffs to get clean water from the government, the community does not object. They argue that the presence of PDAM water flow in their area is very helpful to them. According to one resident, after entering the PDAM water flow in his area he no longer had to queue to get clean water.

Even though the construction of a natural science plant is located in a residential area, it does not mean that the people in the area all get PDAM water pipeline connections. Like the Natural Sciences in Bangaka Subdistrict, located in the village of Kapita, piping connections only reached more than 20 customers. This is caused by the lack of availability of PDAM pipes.

In addition, there are a number of people living in urban areas who also continue to use wellbore water, even though they have obtained piped water piping connections. This apparently had an impact on PDAM revenues. Because these customers only pay the burden. Regarding this matter, up to now the Jeneponto Regency PDAM has not provided sanctions or reprimands. 


\section{CONCLUSION}

The institutional capacity in managing clean water in Jeneponto Regency still has a number of shortcomings, so this is what causes problems in the management of clean water in Jeneponto Regency. These deficiencies include: 1) employees involved in clean water management have low skills, and have educational backgrounds that are not at work's level; 2) Agencies involved in clean water management have not been able to carry out their respective roles; 3) there is no established cooperative and coordination relationship, and; 4) water management plans that are made contrary to applicable rules.

\section{REFERENCES}

Damayanty, S. A. (2013). Fasilitas Pemerintah VS Revitalisasi Manajemen. Buletin Info Risiko Fiskal, Edisi 3, 1-9.

Dunnete, H. (1976). Management. Jakarta: Prehalindo.

Gibson, I., \& Donnelly. (2000). Organisasi dan Manajmen, Perilaku, Struktur, Proses. Jakarta: Erlangga.

Iglesias, A., Garrote, L., Flores, F., \& Moneo, M. (2006). Challenges to Manage the Risk of Water Scarcity. Water Resources Management, 775-788.

McNeill, J. (2016). Scale Implications of Integrated Water Resources Management Politics: Lesson from New Zaeland. Environmental Policy and Governance, 306-319.

Miles, M., Huberman, A. M., \& Saldana, J. (2014). Qualitative Data Analysis: A Method Sourcebook. New York: Routledge.

Mizyed, N. (2009). Impacts of Climate Change on Water Resources Availability and Agricultural Water Demand in the West Bank. Water Resources Management, 20152029.

Nemuan, W. (2013). Metodologi Penelitian Sosial: Pendekatan Kualitatif dan Kuantitatif, Edisi 7. Jakarta Barat: PT. Indeks.

Widyawati, Ida Widianingsih, \& Ramadhan Pancasilawan. (2018). Jaringan Organisasi dalam Pembangunan Kawasan Perkotaan Mamminasata, Sulawesi Selatan. Jurnal Ilmiah Ilmu Adminitrasi Publik, 11-20.

Willems, S., \& Baumert, K. (2003). Institutional Capacity and Climate Actions. France: OECD Environmental Direction. 
304 Jurnal Ilmiah Ilmu Administrasi Publik: Jurnal Pemikiran dan Penelitian Administrasi Publik Volume 9 Number 2, July- December 2019. Page 295-304 